\title{
Characterization of Human Protein C Gene Promoter: Insights from Natural Human Mutants
}

\author{
WOEI TSAY, ${ }^{1}$ YU-MAY LEE, ${ }^{2}$ SHENG-CHUNG LEE, ${ }^{2,3}$ MING-CHING SHEN,${ }^{4}$ and PEI-JER CHEN ${ }^{5}$
}

\begin{abstract}
Human protein $\mathrm{C}$ is a liver-produced plasma anticoagulant. Four heterozygous point mutations located in the promoter region have been identified in families with type $\mathrm{I}$ protein $\mathrm{C}$ deficiency and recurrent venous thrombosis. However, detailed analysis of regulatory elements and their interacting factors remains to be undertaken. This report presents results of biochemical and functional characterizations of several cis-elements located in the 5 '-upstream regulatory region and the trans-acting factors that interact with them. A cloned DNA fragment from nucleotides (nt) $-\mathbf{4 1 8}$ to $+\mathbf{4 5}$ could confer tissue specificity, whereas $\mathrm{nt}-\mathbf{8 8}$ to +45 was sufficient for basal promoter activity of protein $\mathrm{C}$ gene. Five cis-elements corresponding to HNF-1, HNF-3, and NF-I/CTF binding sites have been identified. Four heterozygous mutations have been shown to disrupt HNF3 [mutants of $A(-32) G$ and T(-27)A] and HNF-1 [T(-14)C and $C(-10) T$ ] binding. Mutation in the NF-Ibinding site also significantly impairs the promoter activity. Viewed as a whole, these results indicate that HNF-1, HNF-3, and NF-I/CTF play critical roles in transcriptional regulation of the protein C gene.
\end{abstract}

\section{INTRODUCTION}

$\mathbf{P}$ rotein C is a natural vitamin K-dependent plasma anticoagulant. This zymogen, produced specifically by the liver, can be activated by a thrombin-thrombomodulin complex on the surface of endothelial cells. Activated protein $C$ with its cofactors protein $\mathrm{S}$ and factor $\mathrm{V}$ can degrade coagulation factor Va/VIIIa (Dählback, 1995). Both hereditary protein C deficiency (Gladson et al., 1988) and activated protein C resistance (Dählback, 1995) have been proved to be strong risk factors for venous thrombosis. The current database revealed that the majority of genetic defects in patients with hereditary protein $\mathrm{C}$ deficiency were mutations in the coding region of the protein C gene (Reitsma et al., 1995). Griffin's group (Tsay et al., 1993) first found two heterozygous protein C-deficient families with point mutations in the promoter region. Bertina's group (Poort et al., 1993) and Cooper's group (Berg et al., 1994) found another two protein $\mathrm{C}$-deficient families with mutations in the promoter region. The mutation of $\mathrm{T}(-14) \mathrm{C}$ was found to disrupt the binding of HNF-1 (Berg et al., 1994). The remaining lesions are still uncharacterized.

A majority of the genes encoding plasma proteins involved in hemostasis have liver-specific expression (Furie and Furie, 1988). The gene organization of protein $\mathrm{C}$ is quite similar to those of such other vitamin $\mathrm{K}$-dependent procoagulants as prothrombin and factors VII, IX, and X (Furie and Furie, 1988). Other than their lack of the classic TATA box (Degen, 1992; Huang et al., 1992; Kurachi and Kurachi, 1995), their promoter sequences and transcriptional mechanisms are obviously different. The prothrombin gene has a promoter region (108 bp upstream of transcription initiation site) that contains an HNF1-like sequence and an enhancer region (between -919 and -790) that contains an HNF-1 site (at nt -888 to -876 ), an SP1 site (at nt -834 to -829 ) and an uncharacterized liverspecific sequence (at $n t-822$ to -815 ) (Degen, 1992). The factor X gene promoter has an HNF-4 site (at nt -59 to -49 ) and an uncharacterized cis-element (at nt -132 to -110 ) (Huang et al., 1992; Miao et al., 1992). The factor IX gene promoter contains at least six cis-elements within $240 \mathrm{bp}$. These are C/EBP (at nt +4 to +19 ), HNF-4 (at nt -27 to -19 ), NFI-liver (at nt -99 to -77 ), DBP (at nt -219 to -202 ) in addition to three undetermined units (at $\mathrm{nt}-16$ to $-3,-34$ to -23 , and -67 to -49 ) (Kurachi and Kurachi, 1995). Studies of mutations in the factor IX gene promoter associated with he-

\footnotetext{
${ }^{1}$ Department of Internal Medicine and ${ }^{4}$ Clinical Laboratory, Institute of ${ }^{3}$ Molecular Medicine and ${ }^{5}$ Clinical Medicine, National Taiwan University, College of Medicine, Taipei, Taiwan.

${ }^{2}$ Institute of Biological Chemistry, Academia Sinica, Taipei, Taiwan.
} 
mophilia B Leyden have demonstrated the importance of C/EBP and HNF-4 in the regulation of this gene in the liver. The $5^{\prime}$ flanking sequence of the protein $\mathrm{C}$ gene (Foster et al., 1985) has been published for a decade, but there has been no detailed report to characterize the structure of the protein $\mathrm{C}$ gene promoter. Since the reporting of two protein $\mathrm{C}$-deficient families with $\mathrm{A}(-32) \mathrm{G}$ and $\mathrm{C}(-10) \mathrm{T}$ mutations, there is interest in understanding the pathogenesis of these mutations in the promoter region. This report demonstrates that those single-base mutations disrupt the binding of two crucial transactivating proteins, HNF-1 and HNF-3. Several cis-elements essential for the liverspecific expression of protein $\mathrm{C}$ gene also have been identified.

\section{MATERIALS AND METHODS}

\section{Synthetic oligonucleotides}

Single-stranded oligonucleotides used for sequencing, sitedirected mutagenesis and electrophoretic mobility shift assay (EMSA) were synthesized by Bio-Synthesis (Lewisville, TX).

\section{Construction of plasmids}

Varying lengths of fragments of the $5^{\prime}$-flanking region were amplified by polymerase chain reaction (PCR) from human genomic DNA. The designation of PCR primers was based on the published sequence (Foster et al., 1985). The 5'-oligonucleotides contained XbaI and HindIII sites and two 3'-oligonucleotides: one was [5'-ccactagtcgacTCGTGGAGATACTGCAAGT] spanning from nt +45 to +27 , and the other was [5'-ccactagtcGACAGCCTGGAGTTCGAGTTAATCC] spanning $n t+8$ to -17 , both containing SpeI and SalI sites at the 5 '-end. Both series of fragments were subcloned into a pCRII plasmid (Invitrogen, San Diego, CA). The constructs were sequenced through the regions of the inserts to ensure a correct clone. Some deleted constructs were generated by restriction digestion and filled-in with Klenow fragment if necessary (Fig. 1). All fragments eventually were subcloned into an expression vector $\mathrm{pA}_{3} \mathrm{CAT}$, which was constructed from insertion of a triple repeated sequence of poly(A) tails of SV40 into HindIII site of a plasmid pCAT-basic (Promega, Madison, WI) (Fig. 1). The inserts with the $3^{\prime}$-end at +45 were named the $\mathrm{pC}_{2}$ series; the inserts with the $3^{\prime}$-end at +8 were named the $\mathrm{pC}_{1}$ series. The mutant promoters were constructed by mutant oligonucleotides (Table 1) and a site-directed mutagenesis kit (Promega).

\section{Rat liver nuclear extracts and HeLa cell nuclear extracts}

Liver nuclear extracts from $200-\mathrm{g}$ to $300-\mathrm{g}$ Wistar male rats were prepared (Gorski et al., 1986). Following ammonium sulfate precipitation, protein pellets were dissolved at a concentration of $7 \mathrm{mg} / \mathrm{ml}$ in dialysis buffer $(25 \mathrm{~m} M$ HEPES, pH 7.6, $40 \mathrm{~m} M \mathrm{KCl}, 0.1 \mathrm{~m} M$ EDTA, $1 \mathrm{~m} M$ dithiothreitol, $10 \%$ glycerol, $0.5 M$ PMSF, $0.1 \mathrm{~m} M$ benzamidine, $1 \mu \mathrm{g} / \mathrm{ml}$ pepstatin A, $1 \mu \mathrm{g} / \mathrm{ml}$ leupeptin). Nuclear extracts were dialyzed and then stored in small aliquots at $-135^{\circ} \mathrm{C}$.

The crude HeLa cell nuclear extracts were prepared (Schreiber et al., 1989) and used in EMSA only.

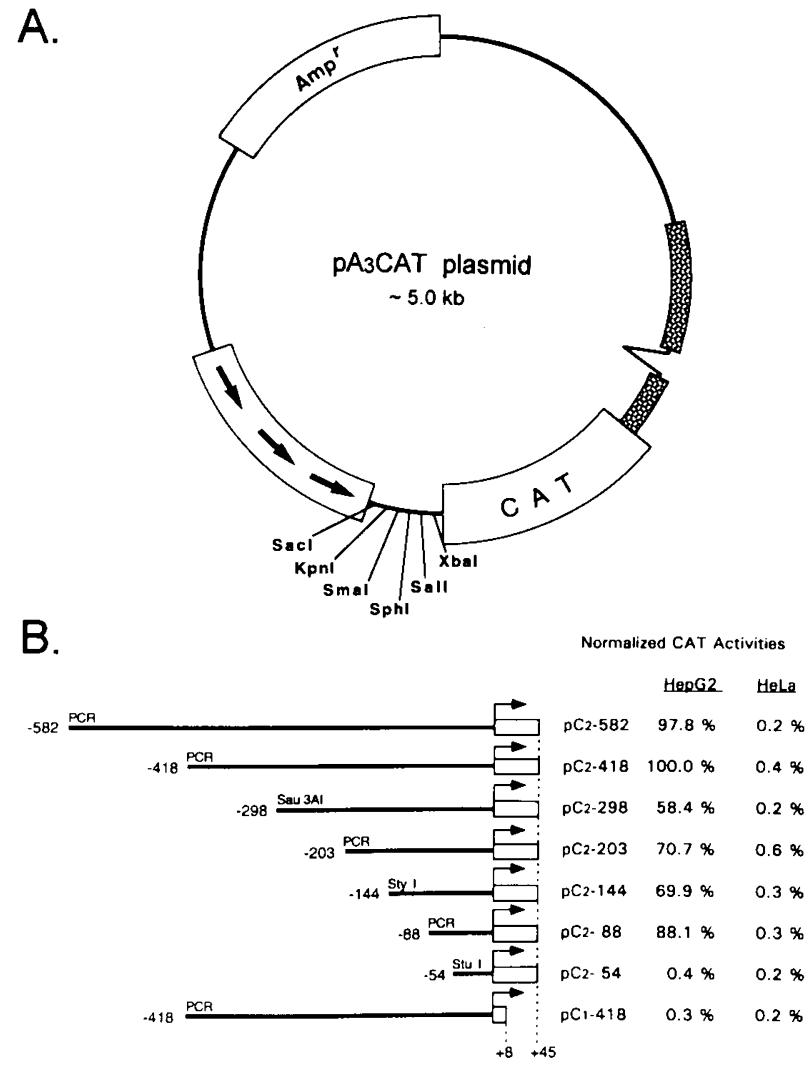

FIG. 1. The $\mathrm{pA}_{3} \mathrm{CAT}$ reporter constructs and their transcriptional activity. (A) A 730-bp triple repeated sequence of poly A tails of SV40 was inserted into the HindIII site of pCATbasic plasmid to minimize the background activity. Then, varying length fragments of 5 '-flanking region with progressive deletion were subcloned into the multiple cloning sites of $\mathrm{pA}_{3} \mathrm{CAT}$ reporter plasmid. (B) The $\mathrm{pC}_{2}$ series owned inserts with the $3^{\prime}$-end at $\mathrm{nt}+45$ and the $\mathrm{pC}_{1}$ series at $\mathrm{nt}+8$. The number of each construct denotes the insert 5 -end. Expression activity was measured by CAT activity of cellular proteins in $\mathrm{HepG}_{2}$ or HeLa cells. The construct $\mathrm{pC}_{2}-418$, carrying the fragment of nt -418 to +45 , in $\mathrm{HepG}_{2}$ is arbitrarily assumed to give $100 \%$ CAT activity. Other results are represented as a percent of the maximum. The values of constructs in HeLa cells are similar to the background levels. All results derived from the average with standard error of five to eight transfection experiments.

\section{EMSA}

To assess each putative candidate in footprint areas, several synthetic oligonucleotides were designed, as shown Table 1. The basic procedure of EMSA was described previously (Lee et al., 1993). Double-stranded oligonucleotides used in EMSAs were prepared by mixing equimolar amounts of sense and antisense strands of each corresponding synthetic oligonucleotide. These oligonucleotides were 5 '-end-labeled with [ $\left.{ }^{32} \mathrm{P}\right]-\mathrm{dATP}$, or with $\left[{ }^{32} \mathrm{P}\right]-\mathrm{dCTP}$ and Klenow fragment, to a specific activity of about $1 \times 10^{9} \mathrm{cpm} / \mu \mathrm{g}$ and used as probes in EMSAs.

Two to five micrograms of rat liver nuclear extracts were used in each reaction. Since NF-I/CTF proteins (members of the nuclear factor I/CCAAT transcription factor family) in HeLa cells had been characterized, the crude HeLa cell nuclear ex- 
Table 1. Sequences of Oligonucleotides Used in This Study ${ }^{\mathrm{a}}$

1. Oligonucleotides for site-directed mutagenesis

1A [C(-10)T]: CTGGAGTTCGAATTAATCCATAACC

1B [T(-14)C]: GTTCGAGTTAGTCCATAACCAC

3A [T(-27)A]: CCATAACCACATATATTTGCTTGG

3B [A $(-32) \mathrm{G}]$ : CCACAAATATCTGCTTGGC

3C (distal HNF-3 site): CTCTCCATAGACCTCGAGTGGCACTAG

3M (proximal NF-I site): CACAAATATTTGCTTCTCGAGCAGCACTGAGGC

3N (distal NF-I site): AGGCCTCCCTCGAGATAGACAAACAGTGG

2. Consensus sequences for EMSA

HNF-1: tcgaACTGTCAAATATTAACTAAAGG (from rat $\beta$-fibrinogen -99 to -77 )

HNF-3: tcgaACTAAGTCAATAATCAGA (from TTR HNF-3 site)

HNF-4: tcgaGCGCTGGGCAAAGGTCACCTGC (from human apoCIII)

HNF-5: tcgaCTAGAACAAACAAGTCCTGCG (from TAT HNF-5 site)

NF-I/CTF: TATTTTGGATTGAAGCCAATATGATAATG (from adenovirus type 2 ori.)

C/EBP: tcgaGTTAGGGTGTGGAAAGTCCC (from SV40 core C)

AP3: tcgaGCGCTGGGCAAAGGTCACCTGC (from SV40 enhancer)

3. Oligonucleotides (wild-type and mutant) for EMSA (only sense strands shown)

PC25/07: tcgaGTGGTTATGGATTAACTCG

1A[C $(-10)$ T]: tcgaGTGGTTGTGGATTAATTCG

1B[T(-14)C]: tcgaGTGGTTATGGACTAACTCG

PC39/18: tcgaCCAAGCAAATATTTGTGGTTA

3A[T(-27)A]: tcgaCCAAGCAAATATÁTGTGGTTA

3B[A(-32)G]: tcgaCCAAGCAG

PC50/04: tcgaGTGCTGAGGGCCAAGCAAATATTTGTGGTTATGGATTAACTCGAAC

PC54/32: tcgaCTCAGTGCTGAGGGCCAAGCAA

PC70/51: tcgaTCTATGGAGAGGGAGGCC

PC99/56: tcgAGGACCAGGAGTGCTAGTGCCACTGTTTGTCTATGGAGAGGGAG

PC84/62: tcgaGTGCCACTGTTTGTCTATGGAG

PC108/59: tcgaTGCTGAGCTAGGACCAGGAGTGCTAGTGCCACTGTTTGTCTATGGAGAGG

${ }^{\text {a }}$ The bases changed are underlined in the mutated oligonucleotides.

traction was applied in the identification of NF-I cis-elements. Protein-DNA complexes were formed in a $20-\mu$ l total volume. After incubation for $20 \mathrm{~min}$ on ice or at room temperature, 1 $\mu \mathrm{l}$ of $0.1 \%$ bromophenol blue was added, and the samples were directly loaded onto a 5\% polyacrylamide gel (39:1 acrylamide/bisacrylamide) containing $4 \%$ glycerol. Electrophoresis was performed with $100 \mathrm{~V}$ at room temperature or at $4^{\circ} \mathrm{C}$.

\section{Cell culture, DNA transfection, and CAT assays}

$\mathrm{HepG}_{2}, \mathrm{CV}-1$, or HeLa cells were cultured as a monolayer in Dulbecco's modified Eagle's medium supplemented with $10 \%$ fetal calf serum. DNA transfections were performed by the calcium-phosphate precipitation technique. For each $10-\mathrm{cm}$ diameter plate, the calcium phosphate-DNA precipitate contained $15 \mu \mathrm{g}$ target plasmid and various amounts of effector plasmids, pRSV/HNF-1 (Chouard et al., 1990), pCMV/HNF$3 \alpha$ (Lai et al., 1990), pCMV/HNF-3 $\beta$ (Lai et al., 1991), $\mathrm{pCMV} / \mathrm{HNF}-3 \tau$ [the cDNA of HNF-3 $\tau$ taken from pTZ18U/HNF-3 $\tau$ (Lai et al. 1991) and subcloned into pCMV expression vector], pLEN4S (Sladek et al. 1990), pCMV/NF-I [the cDNA of NF-I taken from pMT-NF-I (Nehls et al. 1991), then subcloned into pCMV expression vector], or pEFC/EBP $\alpha, \beta, \delta$ (Nishiyori et al., 1994). Plasmid pGEM $3 Z$ or $4 Z$ DNA was used as a carrier to give a total plasmid amount of $20 \mu \mathrm{g}$ in each assay. Cells were harvested $48 \mathrm{hr}$ after transfection, and $30 \mu \mathrm{g}$ of total protein was used to perform a CAT assay by thin-layer chromatography. CAT activity was measured by phosphoimager. To correct for differences in DNA trans- fection efficiencies, the cells were cotransfected with a reference plasmid carrying the $\beta$-galactosidase gene under control of the SV40 early promoter enhance, $\mathrm{pSV}$ - $\beta$-galactosidase plasmid. After transfection, CAT activities were measured and normalized to the $\beta$-galactosidase activity.

\section{DNase I footprinting analysis}

DNase I footprinting assay was performed (Galas and Schmitz, 1978). One nanogram of a 197-bp end-labeled DNA fragment (spanning nt -147 to +45 ) from plasmid by restriction enzymes StyI and SalI digestion, was added to a $20 \mu \mathrm{l}$ reaction mixture containing $25 \mathrm{mM}$ HEPES (pH 7.8), $60 \mathrm{mM} \mathrm{KCl}$, 7.5\% glycerol, $0.1 \mathrm{mM}$ EDTA, $5 \mathrm{mM} \mathrm{MgCl}$, and $1 \mu \mathrm{g}$ of double-stranded poly(dI-dC) DNA (Pharmacia Biotech, Piscataway, NJ). Two to sixteen micrograms of crude rat liver nuclear extract was added last, and the binding reaction was allowed to proceed for $90 \mathrm{~min}$ on ice. An appropriate amount of DNase I, freshly diluted in $10 \mathrm{mM} \mathrm{MgCl}$ and $5 \mathrm{mM} \mathrm{CaCl}$, was added. Digestion was performed on ice for 2-3 min and halted by the addition of $50 \mu$ l of solution containing $20 \mathrm{mM}$ EDTA, $0.5 \%$ SDS. The samples were then extracted with phenol-chloroform and precipitated with ethanol at $-70^{\circ} \mathrm{C}$. The DNA pellets were dried, resuspended in formamide dye $(95 \%$ formamide, $1 \%$ xylene cyanol $\mathrm{FF}, 1 \%$ bromophenol blue), heated at $90^{\circ} \mathrm{C}$ for $3 \mathrm{~min}$, and loaded onto $6 \%$ polyacrylamide$7 M$ urea sequencing gel, followed by autoradiography. A sequence ladder was prepared from M13 ssDNA by Sequenase kit (United States Biochemical, Cleveland, $\mathrm{OH}$ ). 
Competitive footprinting analysis was performed by adding various amounts of the appropriate double-stranded oligonucleotide as competitor to the reaction mixture containing poly (dI-dC) and liver nuclear extracts, resting on ice for $15 \mathrm{~min}$ before the addition of the end-labeled fragment. The other procedures were as described.

\section{RESULTS}

\section{Transcriptional control and liver-specific expression of} human protein $C$ gene

To characterize sequences responsible for transcriptional regulation of the human protein $\mathrm{C}$ gene, a $5^{\prime}$-flanking segment from nt -418 to +45 was linked to a bacterial CAT gene in a promoterless reporter plasmid $\mathrm{pA}_{3} \mathrm{CAT}$ (Fig. 1). The resulting construct was transfected into $\mathrm{HepG}_{2}, \mathrm{CV}-1$, or HeLa cells. Transient gene expression was monitored by measuring CAT activity in the cell extracts. The parent plasmid $\mathrm{pA}_{3} \mathrm{CAT}$, which does not express CAT activity, was employed as a negative control. The plasmid pCMV-CAT, which contains the CMV promoter-enhancer sequences upstream of the CAT gene, was used as a positive control. The $\mathrm{pC}_{2}-418$ construct (nt -418 to +45 ) exhibited a more than 200 -fold higher expression in $\mathrm{HepG}_{2}$ cells than in HeLa cells (Fig. 1). The expression activity in CV-1 cells was about 20 -fold higher than that in HeLa cells (data not shown). These results indicate that this promoter has liverspecific expression.

A various number of serial reporter constructs containing different length fragments of the 5 '-flanking region were transfected into $\mathrm{HepG}_{2}$ cells. The construct $\mathrm{pC}_{2}-418$ had the maximal promoter activity. The transcriptional activity decreased to $58.4 \%$ when it was cut to nt -298 , which suggests a weak positive regulator between $n t-418$ and -298 . Further deletion could slightly improve the promoter activity, especially deleting the fragment $\mathrm{nt}-144$ to -88 , which probably contains a weak negative regulator. However, the activity drastically returned to background level after deletion beyond $\mathrm{nt}-88$. If the 3 -end was deleted to $\mathrm{nt}+8$, the promoter activities were completely abolished also. Thus, the major basal elements required for protein $\mathrm{C}$ promoter activity are contained within the region of $n t-88$ to +45 .

\section{Identification of the regulatory elements in the 5'-flanking region}

To further localize and identify the cis-elements, DNase I footprint analysis was performed by using a probe derived from $\mathrm{nt}-147$ to +45 (Fig. $2 \mathrm{~A}$ ). Even using as little as $2 \mu \mathrm{g}$ of rat liver nuclear extract in a $20 \mu \mathrm{l}$ reaction, a region from $\mathrm{nt}-5$ to -144 was nearly fully protected. Several adjacent protected regions could be roughly identified: first from nt -3 to -44 , second from $n t-52$ to -108 , and third from $n t-110$ to -145 . Another weak protected region from $n t-2$ to +19 was noted when the amount of liver nuclear extracts was increased. Through comparing the published consensus binding sequences of known transcriptional factors (Faisst and Meyer, 1992), several putative cis-elements were noted, including HNF-1, C/EBP, activator protein-3 (AP3), HNF-3, NF-I, HNF-4, and androgen/glucocorticoid response element (ARE/GRE) (Fig. 2B).
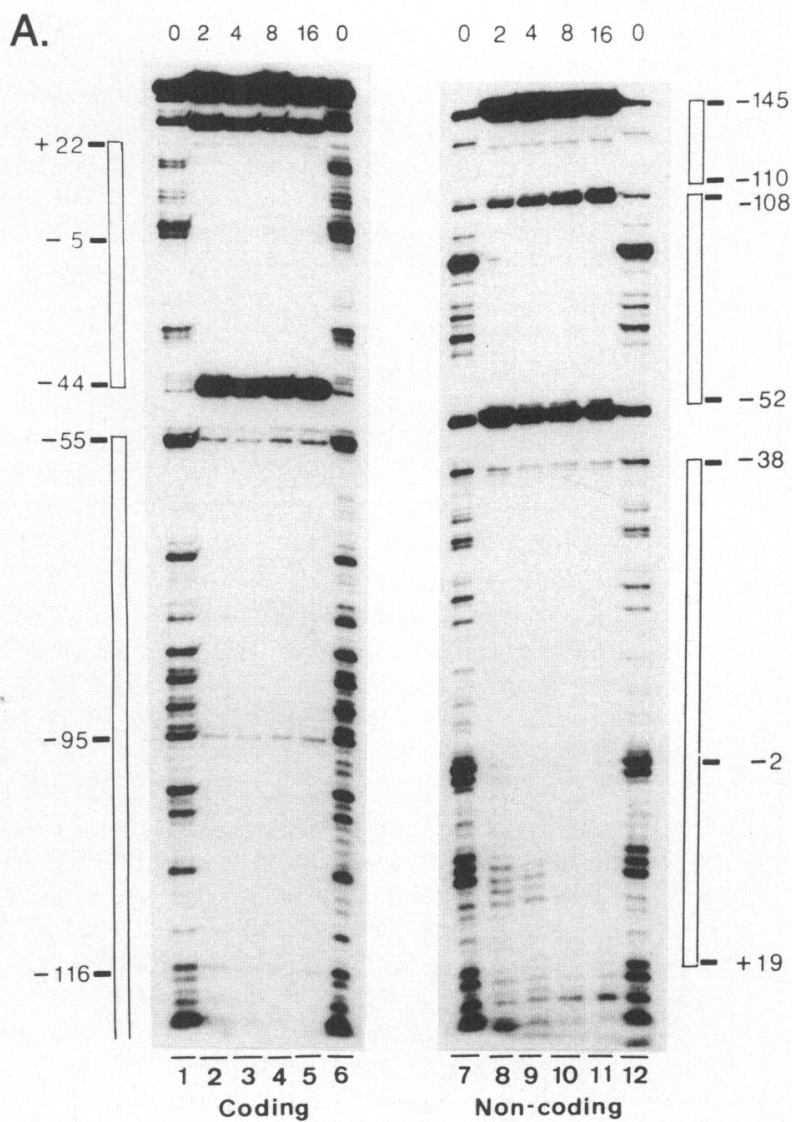

B.

-170 CCTCCCTCCC TGCTGGATGG CATCCTTGGT AGGCAGAGGT

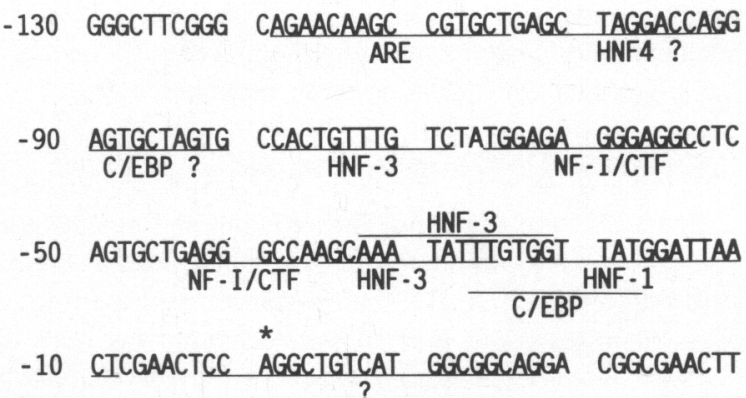

FIG. 2. DNase I footprinting analysis and the nucleotide sequence of protein C promoter. (A) DNase I footprinting analysis of coding and noncoding strands spanning nt -147 to +45 . DNA fragments end-labeled by $\left[{ }^{32} \mathrm{P}\right]-\mathrm{dCTP}$ and Klenow fragment at the SalI site for coding strand and at the StyI site for noncoding strand were subjected to DNase I digestion in the absence $(0 \mu \mathrm{g})$ or presence of $2,4,8$, or $16 \mu \mathrm{g}$ (top of photo) of rat liver nuclear extracts. The boxes indicate the protected areas. (B) The nucleotide sequence of the 5'-flanking region of the human protein $\mathrm{C}$ gene. The numbers at left indicate the nucleotide numbering (Foster et al., 1985). Underlining or superlining indicates putative protein binding motifs. The question marks indicate undefined units. The asterisk indicates the transcription initiation site. 


\section{HNF-1 binding site}

The region spanning $\mathrm{nt}-10$ to -23 is highly homologous to the HNF-1 binding site, 5'-(G/A)GTTAATN(A/T) TTA(C/A) (C/A/T) (A/C)-3' (Tronche and Yaniv, 1992) (Fig. 3A). In EMSA, an oligonucleotide with a strong HNF-1 binding site from rat $\beta$-fibrinogen promoter (nt -99 to -77 ) (Tronche and Yaniv, 1992) competed efficiently with the labeled PC25/07 oligonucleotide (spanning nt -25 to -7 ) for a protein-DNA complex (Fig. 3B, left). Furthermore, the PC25/07 oligonucleotide competed largely with the labeled rat fibrinogen HNF-1 oligonucleotide for the same complex (Fig. 3B, right). We concluded that the PC25/07 oligonucleotide carries an HNF-1 site. To test the binding influenced by mutations $\mathrm{C}(-10) \mathrm{T}$ and $\mathrm{T}(-14) \mathrm{C}$, two mutant oligonucleotides were designed (Table 1). EMSA demonstrated that the mutant $\mathrm{C}(-10) \mathrm{T}$ or $\mathrm{T}(-14) \mathrm{C}$ oligonucleotide hardly competed with the labeled wild-type PC25/07 oligonucleotide or HNF-1 consensus oligonucleotide (Fig. 3B). Our data have demonstrated that both mutations induced disruption of HNF-1 binding.

The functional activity of wild-type and mutant reporters was tested by the transient transfection assay in $\mathrm{HepG}_{2}$ cells. Both $\mathrm{C}(-10) \mathrm{T}$ and $\mathrm{T}(-14) \mathrm{C}$ mutant constructs resulted in drastic reduction of transcription activity to $5.4 \%$ and $5.0 \%$, respectively, as compared with the wild-type construct (Fig. 3C, left). Further testing of the transactivating activities of pRSV/HNF-1 expression vector for the wild-type and mutant promoters employed HeLa cells because of the absence of HNF-1 from these cells. The results demonstrated that transactivation was also dramatically reduced in mutant $\mathrm{C}(-10) \mathrm{T}$ to $6.4 \%$, and $\mathrm{T}(-14) \mathrm{C}$ to $3.4 \%$, respectively (Fig. $3 \mathrm{C}$, right). The mutations of $\mathrm{C}(-10) \mathrm{T}$ and $\mathrm{T}(-14) \mathrm{C}$ not only disrupted the HNF-1 cis-element but also resulted in a drastic loss of transcriptional activity. Taken together, these findings indicate that HNF-1 is a critical cis-element for protein $\mathrm{C}$ expression.

\section{$H N F-3$ binding sites}

In Figure $4 \mathrm{~A}$, the region spanning nt -24 to -37 , designated as the proximal HNF-3 element, contains two overlapped HNF-3 sites. One is located at $n t-22$ to -33 , and the other is at $\mathrm{nt}-26$ to -37 . Both were homologous to the HNF-3 consensus sequences, $5^{\prime}-(\mathrm{G} / \mathrm{C} / \mathrm{A}) \mathrm{A}(\mathrm{T} / \mathrm{A}) \mathrm{T}(\mathrm{G} / \mathrm{A}) \mathrm{TT}(\mathrm{G} / \mathrm{T})(\mathrm{A} / \mathrm{G})$ (C/T)T(T/C)-3' (Overdier et al., 1994). In EMSA, the PC39/18 oligonucleotide (nt -39 to -18 ) competed with the labeled oligonucleotide with HNF-3 binding site from the mouse transthyretin (TTR) gene (Overdier et al., 1994) (Fig. 4B, left). In contrast, the labeled PC39/18 oligonucleotide formed the duplex protein-DNA complexes (Fig. 4B, right, lane 1), where TTR HNF-3 oligonucleotide also competed for the same duplex protein-DNA complexes (data not shown). The bandshift results supported the hypothesis of a proximal HNF-3 element.

The region spanning from $n t-68$ to -79 bore another HNF3 binding site with high degree of homology to the consensus sequence. In EMSA, the TTR HNF-3 oligonucleotide easily competed with the labeled PC84/62 oligonucleotide (nt -84 to -62) for a weak complex (data not shown). In contrast, the PC84/62 oligonucleotide competed with the TTR HNF-3 oligonucleotide (Fig. 4B, left). Furthermore, in the competition footprinting assay, the protected footprint $n t-68$ to -79 was lost by adding a competitor TTR HNF-3 oligonucleotide (Fig.
6B). These data indicated that another weak HNF-3 site is located between $\mathrm{nt}-68$ to -79 , which is designated as the distal HNF-3 element.

To elucidate the importance of the proximal and distal HNF3 elements for transcriptional activity, several mutant promoters were created, including HNF-3a with mutation $\mathrm{T}$ to $\mathrm{A}$ at $\mathrm{nt}$ -27 , HNF-3b with A to G at nt -32 , HNF-3c with mutation at the distal HNF-3 element, and HNF-3a/3c or HNF-3b/3c with double mutations. The transcriptional activity in $\mathrm{HepG}_{2}$ cells was reduced to $5.6 \%, 7.4 \%$, and $37.9 \%$ for HNF-3a, HNF-3b and HNF-3c, respectively (Fig. 4C, left). In the cotransfection assays with expression vector $\mathrm{pCMV} / \mathrm{HNF}-3 \alpha, \beta, \tau$ in $\mathrm{HeLa}$ cells, the mutant promoter HNF-3a or HNF-3b caused drastically reduced activity. In contrast, mutant promoter HNF-3c reduced activity to $23.5 \%$ only (Fig. $4 \mathrm{C}$, right). If both proximal and distal HNF-3 elements were mutated, promoter activities would be further reduced. These data suggested that three HNF3 sites do exist in the protein $\mathrm{C}$ promoter. Furthermore, the proximal element is more important than the distal one. Clinically, patients with heterozygotic mutations of $\mathrm{T}(-27) \mathrm{A}$ or $\mathrm{A}(-32) \mathrm{G}$ have symptomatic protein $\mathrm{C}$ deficiency. Both mutations cause disruption of the proximal HNF-3 element and crucial loss of transcriptional activity. However, no natural mutation has been found in the distal HNF-3 element.

\section{NF-I/CTF binding sites}

Figure $5 \mathrm{~A}$ shows that the region spanning nt -40 to -36 contains a motif, GCCAA, and the region spanning nt -66 to -63 contains a motif, TGGA. Both are homologous to each half-site of the NF-I/CTF consensus palindromic sequence, TGG(C/A) $\left(\mathrm{N}_{5}\right)$ GCCAA (Gronostajski, 1985). As demonstrated by EMSA, five complexes were formed by HeLa cell nuclear extract and an NF-I consensus oligonucleotide that came from nt 20 to 48 in the adenovirus replication origin (Gronostajski, 1985). The unlabeled PC70/51 or PC54/32 oligonucleotide could compete for the lower three complexes in lane 3 and 4, respectively (Fig. 5B). The unlabeled NF-I consensus probe could compete with the labeled PC70/51 or PC54/32 oligonucleotides for the similar complexes in lane 8 (Fig. 5B). The EMSA performed by rat liver nuclear extracts obtained similar results. The rabbit polyclonal antibodies against the N-terminal of CTF1 proteins could induce a supershift band (data not shown). These results show that both nt -32 to -54 and $n t-51$ to -70 contain a weak binding motif for NF-I/CTF.

To further assess the functional activity of NF-I sites, a mutant construct was created with site-specific mutation replacing nt -38 to -43 (Table 1). The transcriptional activity of this mutant construct in $\mathrm{HepG}_{2}$ cells was reduced by $75 \%$. However, when a mutant construct containing double mutations in both motifs with pCMV/NF-I expression vector was cotransfected into $\mathrm{HepG}_{2}$ or HeLa cells, the transactivation activity of the mutant construct was similar to that of the wild type (data not shown). These data indicate that other NF-I sites exit in the protein $\mathrm{C}$ promoter.

\section{$H N F-4-l i k e$ binding site}

When the $\mathrm{PC}_{2}-418$ reporter was cotransfected with an HNF4 expression vector pLEN $4 S$ in $\mathrm{HepG}_{2}$ cells, the promoter ac- 

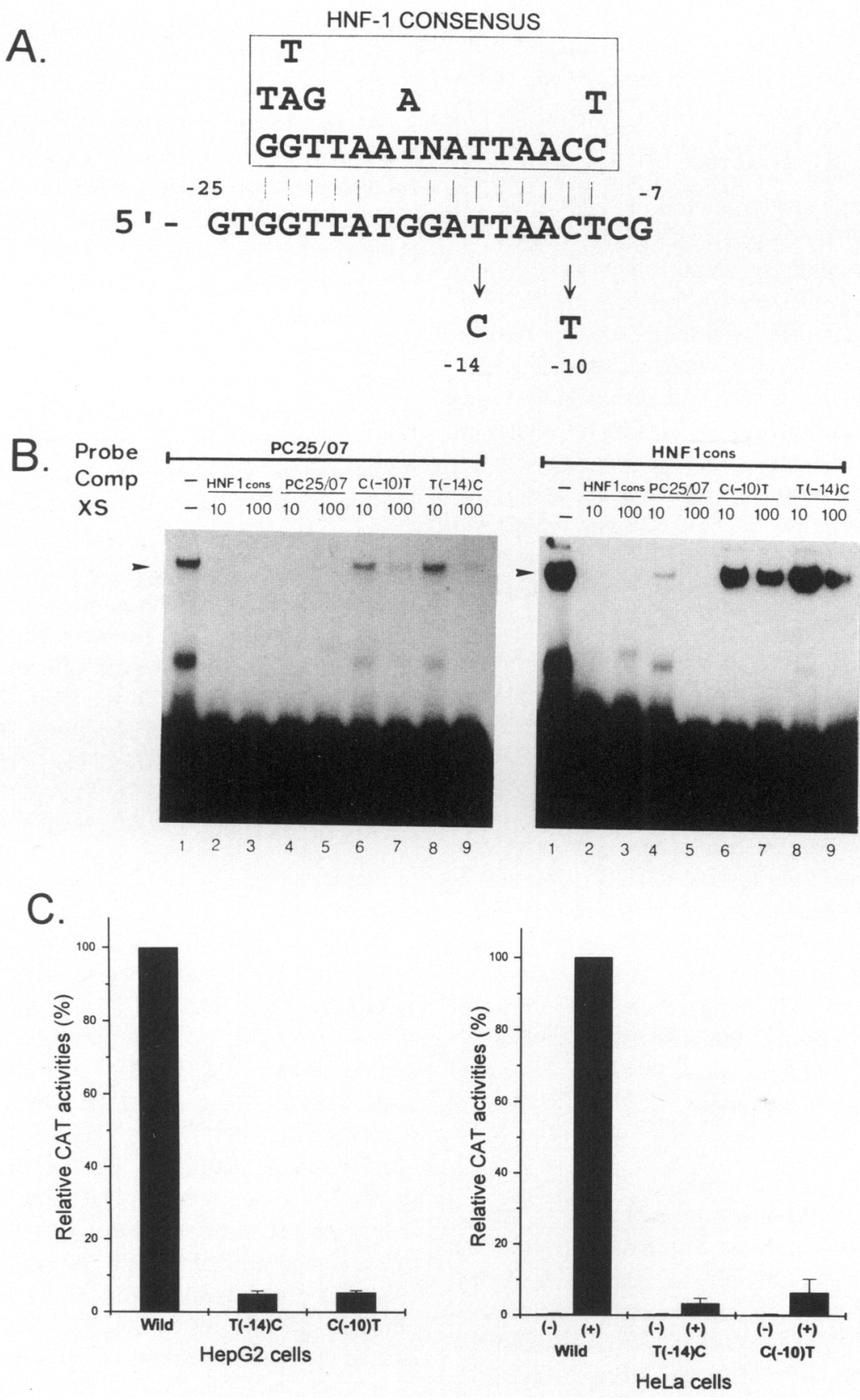

FIG. 3. The HNF-1 binding sites in protein C promoter. (A) The HNF-1 binding site of protein C promoter is shown in comparison with the HNF-1 consensus sequence (Tronche and Yaniv, 1992). Mutations found in human protein C-deficient families at nt -14 and -10 are shown with short vertical arrows at mutant bases. (B) EMSA. The PC25/07 oligonucleotide at left and the HNF-1 consensus oligonucleotide (HNF1 cons) from rat $\beta$-fibrinogen promoter at right were end-labeled by [ ${ }^{32} \mathrm{P}$ ]-dCTP. Addition of the synthetic oligonucleotides as competitors (Comp) at the molar excess (XS) is shown. (C) CAT expression activity of wild and mutant reporters in $\mathrm{HepG}_{2}$ (left) and $\mathrm{HeLa}$ (right) cells. The CAT activity of wild-type construct $\mathrm{pC}_{2}-418$ is arbitrarily assumed as $100 \%$. The marker $(-)$ indicates the absence of expression vector pRSV-HNF- $1 ;(+)$ indicates the presence of $2 \mu \mathrm{g}$ of expression vector. All results derived from the average means with standard error of more than three transfection experiments.

tivity could increase about 1.5 -fold (data not shown), indicating that HNF-4 may play some role in transactivation of the protein $\mathrm{C}$ gene. Figure $6 \mathrm{~A}$ demonstrates that two candidate sequences nt -103 to -92 and $n t-88$ to -77 are highly homologous to the HNF-4 consensus sequence, 5'(G/T)GC(A/T)A(A/G)G(G/T) (T/C) CA (T/C)-3' (Sladek et al.,
1990). As the competition footprinting assay was performed, the unlabeled consensus HNF-4 oligonucleotide [from human apoCIII gene (Sladek et al., 1990)] could induce loss of the footprint between $\mathrm{nt}-108$ and -90 (Fig. 6B). This suggested that a putative HNF-4 site was located at nt -103 to -92 . As EMSA was performed, the consensus HNF-4 oligonucleotide 


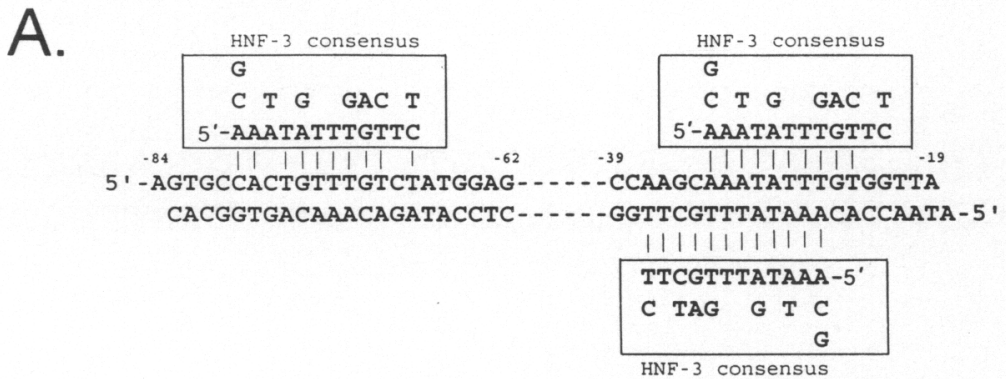

B.
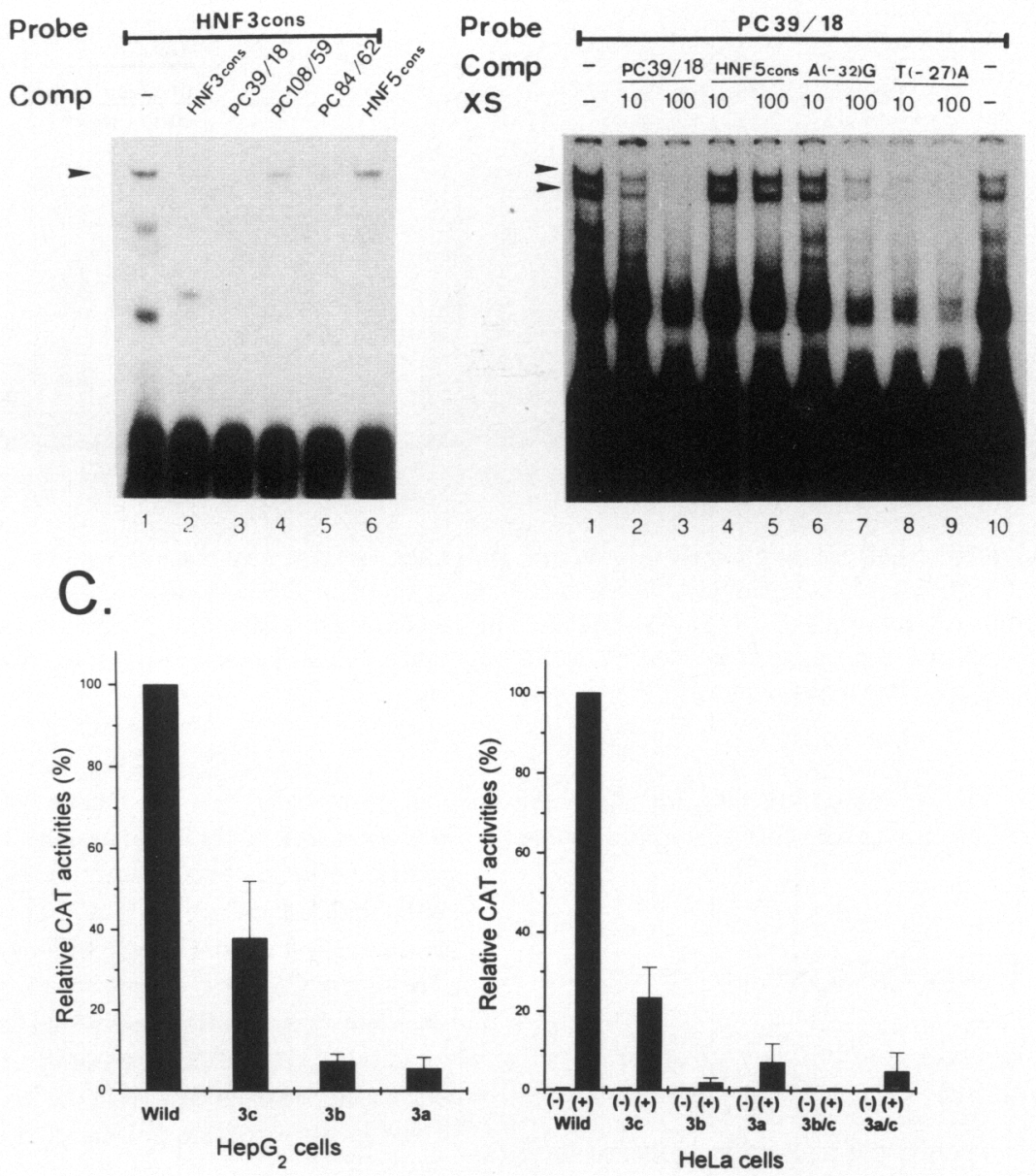

FIG. 4. The proximal and distal HNF-3 elements in protein $\mathrm{C}$ promoter. (A) The sequences of the HNF-3 binding motifs in the protein $\mathrm{C}$ promoter are shown in comparison with the HNF-3 consensus sequence (Overdier $e t$ al., 1994). The sequence at right shows that the proximal HNF-3 element contains two overlapping HNF-3 motifs; the sequence at left shows that the distal element contains an HNF-3 motif. (B) EMSA. (Left) Competitors of 100-fold molar excess competed with the labeled HNF-3 oligonucleotide (HNF3 cons) from mouse TTR gene (Overdier et al., 1994). (Right) Competitors of 10-fold or 100-fold molar excess competed with the labeled PC39/18 oligonucleotide; lane 6 to 9 were mutant oligonucleotides as competitors. (C) The CAT activity of wild-type and mutant constructs in $\mathrm{HepG}_{2}$ (left) and HeLa (right) cells. The mutants $3 \mathrm{a}, 3 \mathrm{~b}$, and $3 \mathrm{c}$ indicate mutation of T(-27)A, A $(-32) \mathrm{G}$, and mutation at the distal HNF-3 element, respectively. The mutants $3 \mathrm{a} / \mathrm{c}$ and $3 \mathrm{~b} / \mathrm{c}$ indicate constructs with double mutations. The marker (+) indicates the presence of $1 \mu \mathrm{g}$ of expression vector pCMV/HNF- $3 \tau$, and $(-)$ indicates the absence of expression vector. The CAT activity of wild-type construct $\mathrm{pC}_{2}-418$ is arbitrarily assumed as $100 \%$. All results derived from the average means with standard error of more than three transfection experiments.

competed with the labeled PC108/59 oligonucleotide for a weak complex (data not shown). To assess the functional activity of this HNF-4 site, a mutant construct $4 \mathrm{M}$ was designed with sitespecific mutation in the HNF-4 site (Table 1). The expression activity of this mutant promoter in $\mathrm{HepG}_{2}$ cells was similar to the wild type (data not shown). This result agreed with the observation that the promoter activity of $\mathrm{pC}_{2}-88$ construct, which omitted this HNF-4 site, was similar to that of the $\mathrm{pC}_{2}-144$ con- 


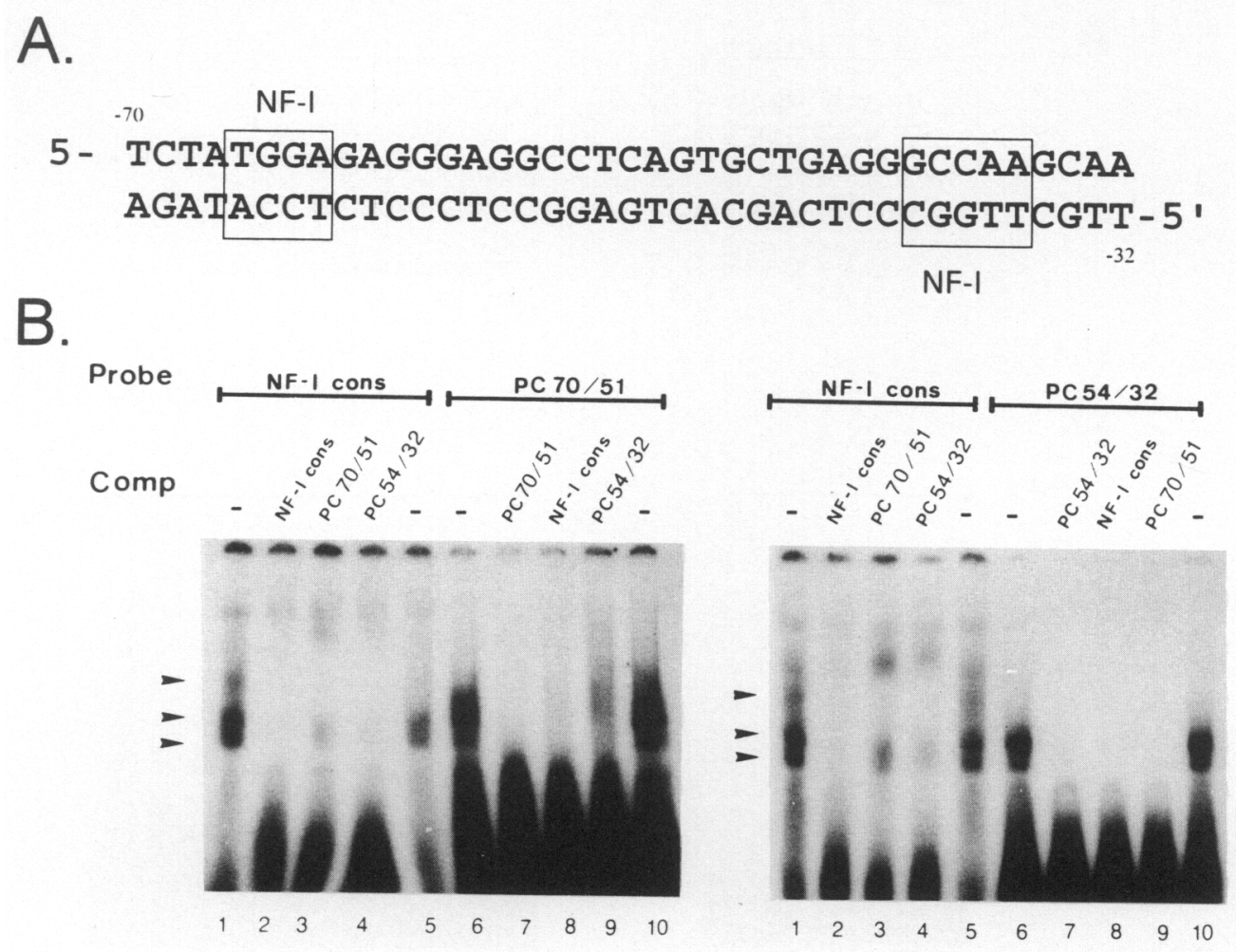

FIG. 5. Two putative NF-1 half-binding motifs in protein $\mathrm{C}$ promoter. (A) The sequence nt -40 to -36 GCCCAA and the sequence nt -66 to -63 TGGA are compatible with the half-binding motif of the consensus sequence of NF-I/CTF (from NF-I site of adenovirus origin) (Gronostajski, 1985). (B) EMSA. The labeled oligonucleotides of the consensus sequence were used in lanes 1-5 of both left and right panels, labeled PC70/51 oligonucleotides in lanes 6-10 (left), and PC54/32 in lanes 6-10 (right). The competitors are shown at the top of the panels.

struct in $\mathrm{HepG}_{2}$ cells (Fig. 1). Taken together, the study indicates that the HNF-4 site is not crucial for basal transcriptional activity in $\mathrm{HepG}_{2}$ cells.

\section{DISCUSSION}

\section{Identification of promoter and characterization of liver-specific expression}

Since Foster et al. reported the nucleotide sequence of the human protein $C$ gene in 1985 , the structure and nature of protein $\mathrm{C}$ promoter have remained obscure. The nontranslated exon 1 was located more than $1 \mathrm{~kb}$ upstream of exon 2 . Recently, Miao and Davie (1995) reported that the protein $C$ gene has multiple transcriptional initiation sites clustered around $\mathrm{nt}+1$, the putative beginning of exon 1 . Analyzing the 5'-flanking region upstream transcription initiation site showed that there was no typical TATA box or CAT box. Previously, we described two heterozygotic mutations found in the 5 '-flanking region associated with symptomatic protein C deficiency (Tsay et al., 1993). In this report, there is further identification of the promoter and 5'-flanking DNA sequences that regulate expression of protein $\mathrm{C}$. The minimal transcriptional unit was restricted in a narrow DNA fragment from nt -88 to +45 , which included a TATA-less core promoter and initiator element. It was clearly demonstrated here that this promoter is a liver-specific expres- sion. As revealed by other current studies, the nature of many liver-expressed genes largely results from cooperation of liverspecific and ubiquitous transactivation factors (Lai and Darnell, 1991; Sladek and Darnell, 1992). The majority of liver-specific transactivation factors belong to four families: HNF-1, HNF-3, $\mathrm{HNF}-4$, and C/EBP. The present study confirmed this hypothesis, identifying multiple cis-elements in the protein $\mathrm{C}$ promoter bound by liver-specific transcriptional factors. It should be especially emphasized that HNF- $1 \alpha$ and HNF-3 are critically involved in the expression of the protein $\mathrm{C}$ gene.

\section{Hepatic nuclear factor-1 $\alpha$}

HNF- $1 \alpha$ is a homeodomain protein that binds to its cognate site as a dimer. It is a key regulator of many genes with liverspecific expression (Lai and Darnell, 1991; Sladek and Darnell, 1992). Using EMSA, it was demonstrated that the sequence of nt -25 to -7 can bind HNF-1 $\alpha$. The overexpression of HNF$1 \alpha$ in either $\mathrm{HepG}_{2}$ or nonhepatoma cells, CV-1 or HeLa cells, resulted in significant stimulation of transcription of protein $\mathbf{C}$ gene promoter. Two naturally occurring single base-pair mutations, $\mathrm{C}(-10) \mathrm{T}$ and $\mathrm{T}(-14) \mathrm{C}$ in the promoter, provided an excellent chance to understand the importance of HNF-1 $\alpha$ in a regulatory role of transcription. The $\mathrm{C}(-10) \mathrm{T}$ mutation happens at the second base of the HNF-1 $\alpha$ motif, whereas the $\mathrm{T}(-14) \mathrm{C}$ mutation happens near the center of the motif (Fig. 3A). Both mutations exchange the highly preserved bases of 


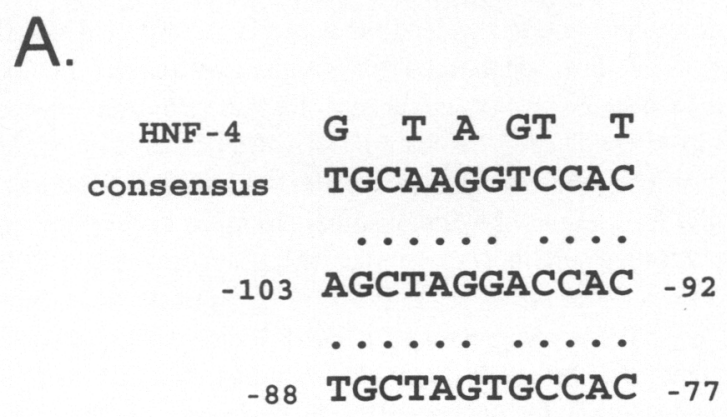

B.

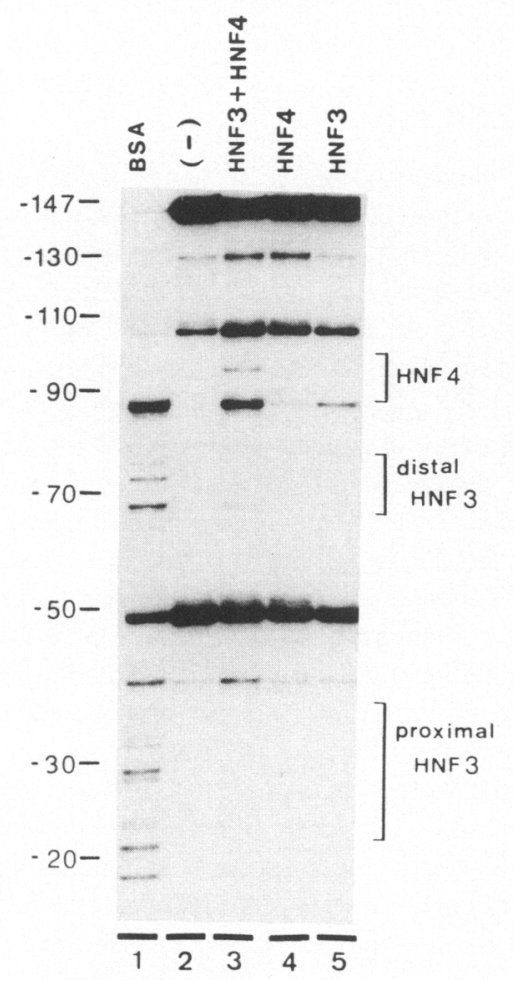

FIG. 6. HNF-4-like sites in protein C promoter. (A) Two putative HNF-4 sites in the protein $\mathrm{C}$ promoter are shown in comparison with the HNF-4 consensus sequence (Sladek et al., 1990). (B) The competitive footprinting assays show the loss of protected areas by addition of either the TTR HNF-3 probe (Overdier et al., 1994) (lane 5) or the human apoCIII HNF-4 probe (Sladek et al., 1990) (lane 4). Lane 3 shows the presence of both competitors, lane 2 is absent of competitor, and lane 1 has BSA instead of rat liver nuclear extracts as control. The nucleotide position is marked at left, and the position of the putative binding sites is indicated at right.

HNF- $1 \alpha$ consensus sequence (Tronche and Yaniv, 1992). As expected, the EMSA demonstrated that both mutations obviously disrupt HNF-1 $\alpha$ binding, even though $\mathrm{C}(-10) \mathrm{T}$ occurred near the margin of this motif. Furthermore, the expression of mutant promoters in $\mathrm{HepG}_{2}$ cells was remarkably reduced by about $95 \%$ as compared with the wide-type promoter. The cotransfection assays of mutant promoter with HNF- $1 \alpha$ expression vector in HeLa cells gave similar results to those with the wide-type one. These data paralleled well the previous obser- vation that the affected members in the family with heterozygotic mutation of $\mathrm{C}(-10) \mathrm{T}$ had only $40 \%$ of plasma protein $\mathrm{C}$ levels as compared with healthy controls (Tsay et al., 1993). Study showed that the defective allele may scarcely express protein $\mathrm{C}$. We concluded that HNF-1 $\alpha$ may be one of the most critical transcriptional factors predominantly regulating the expression of the protein $\mathrm{C}$ gene.

\section{Hepatic nuclear factor-3}

The HNF-3/forkhead family contains three known distinct hepatocyte transcription factors, HNF- $3 \alpha, \beta, \tau$, plus a number of developmental regulators, the Drosophila homeotic forkhead proteins, and other members. The HNF-3 binds to DNA as a monomer through a modified helix-turn-helix, known as "the winged helix motif." One $\alpha$-helix $\mathrm{H}_{3}$ embeds into the DNA major groove, and the other helices $\mathrm{H}_{1}$ and $\mathrm{H}_{2}$ contact the phosphate backbone. Two wing loops, $\mathrm{W}_{1}$ and $\mathrm{W}_{2}$, interact with the more distal parts of the DNA target site (Brennan, 1993). An HNF-3 only contacts the sense strand bases. Figure 4A shows three HNF-3 binding sites in the promoter. The proximal HNF3 element is located between $n t-37$ and -22 , and the distal element is at $\mathrm{nt}-79$ to -69 . Interestingly, the proximal element contains two overlapping binding sites. Each HNF-3 binds the opposite strand. As duplex complexes appeared by the PC39/18 oligonucleotide with rat liver nuclear extract in EMSA (Fig. 4B, right), it is hypothesized that these two HNF-3 proteins may interact with one another in proximal elements and form a dimer complex.

Two naturally occurring mutations of $\mathrm{T}(-27) \mathrm{A}$ and $\mathrm{A}(-32) \mathrm{G}$ both attack the proximal HNF-3 element, causing significant reduction of about $96 \%$ in CAT expression in $\mathrm{HepG}_{2}$ cells. The current data paralleled well clinical observations that those patients with heterozygotic mutation of $\mathrm{T}(-27) \mathrm{A}$ or $\mathrm{A}(-32) \mathrm{G}$ reflected a significant low plasma protein $\mathrm{C}$ level (Poort et al., 1993; Tsay et al., 1993). However, the sitespecific mutation of the distal HNF-3 element induces significant loss of transcription activity. Reduction of the expression activity of mutant promoter $3 a$ or $3 b$ was far more than that of mutant $3 \mathrm{c}$ (Fig. 4C). It was concluded that the proximal element apparently is much more important than the distal element in transactivating protein $\mathrm{C}$ promoter. The stronger transactivating ability of the proximal element may be partially associated with the special steric structure of two HNF-3 molecules synergistically interacting with each other.

Double mutant $3 b / 3 c$ or $3 a / 3 c$ promoter was compared with single mutant $3 \mathrm{~b}$ or $3 \mathrm{a}$ in cotransfection with effector vector pCMV/HNF3r in HeLa cells (Fig. 4C, right). If the proximal element was disrupted but the distal element was preserved, some residual transcriptional activity was still detectable. These data suggested that the distal HNF-3 element did have a little enhancing effect on the promoter activity.

Comparing the effect of two natural mutations, the mutant $A(-32) G$ promoter had less response to cotransfection of pCMV-HNF-3 than the mutant T(-27)A (Fig. 4C, right). This observation agreed with the EMSA (Fig. 4B, right), which showed the mutant $A(-32) G$ probe had less ability to compete for the duplex complexes than the mutant $\mathrm{T}(-27) \mathrm{A}$ probe. From these observations, it was assumed that $\mathrm{A}(-32) \mathrm{G}$ mutation disrupts two overlapping HNF-3 sites in both strands, whereas 
$\mathrm{T}(-27)$ A mutation may only disrupt one HNF-3 site at the sense strand.

\section{Nuclear factor-I}

NF-I/CTF proteins are ubiquitous transactivation factors, consisting of a family of related proteins. There are at least four genes, NFI-A, NFI-B, NFI-C, and NFI-X, which are coded for various NFI proteins. The diversity of NFI- proteins is further increased by differential RNA splicing, leading to different NFIproteins, even in a given family (Santoro et al., 1988). NFI-I proteins form dimers in solution (Gronostajski, 1985) and bind to palindromic sequences, $5^{\prime}-\mathrm{TGG}(\mathrm{A} / \mathrm{C}) \mathrm{N}_{5} \mathrm{GCCAA}-3^{\prime}$, as well as half-site sequences ( $\mathrm{Li}$ and Rosen, 1994). The $\mathrm{N}$-terminal DNA binding and dimerization domains of all NFI- proteins are highly conserved, whereas the C-terminal proline-rich transactivating domains are heterogeneous. NFI-/CTF contains a sequence with striking similarity to the heptapeptide repeat, YSPTSPS, of the carboxy-terminal domain (CTD) of RNA polymerase II (Kim and Roeder, 1994a). Both possess this common structural and functional component that can directly interact with the same target, TBP or TFIIB, in general transcription machinery (Tanese et al., 1991; Kim and Roeder, 1994b; Xiao et al., 1994). This proline-rich activation domain of NFI-/CTF not only can facilitate the recruitment (or stabilization) of the TFIID-DNA complex during preinitiation complex assembly (Kim and Roeder, 1994b; Xiao et al., 1994) but also might have the potential to displace or destabilize the contact of the CTD of RNA polymerase II with TFIID, thus accelerating the release of RNA polymerase II from an initiation or early elongation complex (Xiao et al., 1994). Thus, NFI/CTF may play a crucial role in both the transactivation and the initiation of transcription. In the present study, it was demonstrated that both regions $n t-36$ to -45 and $n t-66$ to -63 were weak binding sites for members of the NFI-/CTF family by EMSA. The expression functional assays confirmed that the NFI- proteins play an important role in transcriptional activation in the protein $\mathrm{C}$ gene.

\section{Possible interplay between NFI- and HNF-3}

It is interesting that both NFI- sites were near the HNF-3 binding sites in this promoter. In the proximal HNF-3 element, two HNF-3 molecules overlapped bound to a 16 bp narrow region (from nt -37 to -22 ), which is in tight apposition downstream of an NFI- half-site. The distal HNF-3 element, however, was upstream of another NF-1 half-site. They were face-to-face, as a mirror image. Several studies have mentioned that some genes have a similar situation. At the $\mathrm{eH}$ site of the albumin enhancer (Jackson et al., 1993), an HNF-3 binding site is 2 bp upstream of an NFI-/CTF motif, TGTTTGC-N 2 -TGGC$\mathrm{N}_{8}$-CA. In the SPB gene promoter (Bohinski et al., 1994), an NFI-/CTF motif is 1 bp upstream from an HNF-3 binding site, TGGC- $\mathrm{N}_{8}$-CA-N-TGTTTGT. In the HBV enhancer (Ori and Shaul, 1995), an HNF-3 binding site is 2 bp downstream of an NFI-/CTF motif, TG- ${ }_{6}$-GCCA-N ${ }_{2}$-TGTTTGC. In the protein $\mathrm{C}$ promoter, the proximal $\mathrm{HNF}-3$ element is 2 bp downstream of the NFI-/CTF motif, TATTTGC-N 2 -TGGC-N 6 -CA. The distal HNF-3 element is 3 bp upstream of the NFI-/CTF motif, TGTTTGT- $\mathrm{N}_{3}$-TGGA-N $\mathrm{N}_{8}$-CC. A comparison of their orientations shows the relationship of these two motifs in the protein
$\mathrm{C}$ promoter is quite similar to that in the albumin eH site. The NFI-/CTF downregulated HNF-3 enhancer activity but positively affected other enhancers in the albumin promoter (Jackson et al., 1993). Since the DNA-binding domain of HNF3 is similar to that of histone $\mathrm{H} 5$, the binding of HNF-3 has the ability to organize the nucleosomal structure to help the binding of other neighboring proteins (McPherson et al., 1993). It is expected that the three HNF-3 sites in the protein $\mathrm{C}$ promoter are crucial for enhancement of other liver-specific or ubiquitous factors. Our preliminary data demonstrated that NFI-/CTF could synergically enhance HNF-3-dependent transactivation (unpublished data). That interplay between NFI-/CTF and HNF3 is believed to be crucial for transcriptional activity of the protein $\mathrm{C}$ gene.

\section{$C / E B P$ sites}

Members of the C/EBP family are often found to be involved in the promoter or enhancer of many liver-specific expressive genes (Lai and Darnell, 1991; Sladek and Darnell, 1992). To elucidate the role of the $\mathrm{C} / \mathrm{EBP}$ proteins in regulating the protein $\mathrm{C}$ promoter, biochemical and functional assays were performed. The EMSA revealed that the unlabeled PC39/18 or PC25/07 oligonucleotide could compete with the labeled C/EBP consensus oligonucleotide (from SV40 core C) (Table 1) for the protein-DNA complex (data not shown). Within the sequence $n t-26$ to -10 , there were two putative binding sites for C/EBP, nt -27 to -18 and $n t-19$ to -10 . Because of a high affinity of HNF-1 $\alpha$ or mutual exclusion of HNF- $1 \alpha$ binding or both, the binding of C/EBP to labeled PC25/07 oligonucleotide was not clearly demonstrated in EMSA. The fragment of $n t-99$ to -56 contain another putative binding site, as determined by EMSA. Its detailed location also was barely defined. Moreover, cotransfection of the reporter construct with the expression vector $\mathrm{pEF}-\mathrm{C} / \mathrm{EBP} \alpha$ of either $\mathrm{HepG}_{2}$ or $\mathrm{HeLa}$ cells did not demonstrate significant transactivating activity (data not shown). It was concluded that C/EBP may play a minor role in the basal transcriptional unit.

\section{HNF-4-like site}

The biochemical data clearly demonstrated that the sequence nt -92 to -103 contains an HNF-4 site. However, several known ubiquitous orphan receptors can competitively bind a similar sequence (Sladek et al., 1990). The nature of this site needs further clarification. This region seemed not to contribute much to the basal transcription activity, as there was limited change of reporter activity by deleting the fragment $n t-144$ to -88 (Fig. 1).

\section{ARE/GRE}

A putative ARE/GRE might exist upstream of an HNF-4like site. The sequence of $\mathrm{nt}-105$ to -119 , A $\underline{\mathrm{GC}} \underline{\mathrm{ACG}}-$ GCTTGTTCT, was highly homologous $(80 \%)$ to the consensus sequence of ARE/GRE, GGTACAnnnTGTTCT (Beato, 1989). The plasma level of protein $C$ was increased 1.6-fold after an androgen analog stanozolol was used for 2 weeks in healthy volunteers or patients with protein $\mathrm{C}$ deficiency (Broekmans et al., 1987). Furthermore, there was a significant change in plasma protein $\mathrm{C}$ levels in males after adolescence 


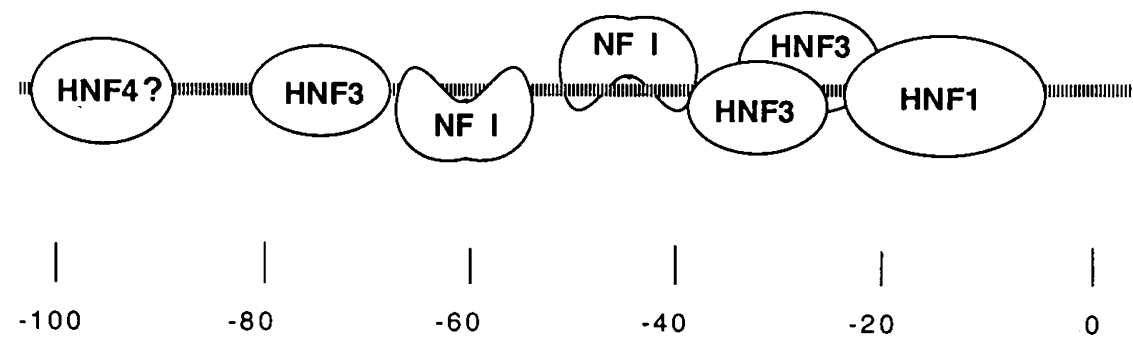

FIG. 7. Hypothetical model of the cis-elements in protein $\mathrm{C}$ promoter. The CAT expression of serial-deletion constructs showed the fragment $\mathrm{pC}_{2}-88$ (nt -88 to +45 ) contains basal transcriptional activity. Within this narrow region, an HNF-1 $\alpha$, three HNF3 , and two NF-I motifs assembled. There are several undetermined units at $\mathrm{nt}-3$ to +19 and another region. Their mutually synergistic interaction may initiate an effective transcription.

(Tait et al., 1993). Whether the stimulation effect occurs directly through androgen or glucocorticoid receptors or indirectly through other transcription activator remains to be clarified. The Leyden region in the promoter of factor IX also contains an HNF-4 site and an ARE-like site. However, in the Leyden region, the HNF-4 site and ARE-like site overlap, and their related proteins occupy this region in a mutually exclusive pattern (Kurachi and Kurachi, 1995). In contrast, the HNF4-like site in the protein $\mathrm{C}$ gene promoter is just downstream from the putative ARE/GRE site. It is known that the specific hormone response of the ARE/GRE element is quite dependent on the neighboring DNA elements (Robins et al., 1994). Whether or not the ARE/GRE in the protein C promoter interacts with other contiguous cis-elements needs further investigation.

\section{Other cis-elements}

The footprinting assays demonstrated that the region of $n t$ -2 to +19 was protected during gradually increased concentration of liver nuclear extract. Constructs were created of variable length 5 '-flanking fragments with the 3 '-end from $n t+8$. The CAT expression activities of these constructs were undetectable. Taken together, these data indicate that the fragment of -2 to +19 must contain some cis-element(s) essential for the basal transcriptional activity of this promoter. It might be the so-called initiator element. In the competition footprint assay, once an HNF-4 consensus probe was added, the region $\mathrm{nt}$ +1 to +6 lost protection (data not shown). However, the sequence of this region is apparently not compatible with the HNF-4 consensus sequence. While this article was in preparation, Miao and Davie declared that a unique and liver-specific protein could bind around the transcription initiation site (Miao and Davie, 1995). The nature of this element should be further clarified.

The sequence of $n t-24$ to -19 , TGTGGTA, was highly homologous to the consensus sequence of $\mathrm{AP}_{3}, \mathrm{TGTGG}(\mathrm{A} / \mathrm{T})$ (A/T) (A/T) Mercurio and Karin, 1989). The EMSA showed that the PC25/07 oligonucleotide could compete with a labeled oligonucleotide with an $\mathrm{AP}_{3}$ site (Table 1) from the $\mathrm{SV} 40$ core region (Mercurio and Karin, 1989) for a protein-DNA complex (data not shown). However, competitive footprint protection studies showed no significant change of footprints by addition of excess $\mathrm{AP}_{3}$ consensus probe.

The untranslated exon 1 has another putative SP1 site at nt +53 to +45 with the sequence GGGGCGGGT, which was ho- mologous to the consensus SP1 binding sequence (Faisst and Meyer, 1992). However, the reporter containing nt -88 to +45 had sufficient basal transcriptional activity. In spite of SP1 possibly having some enhancing effect, it seems not to involve basal transcription.

This study characterized the promoter of the protein $\mathrm{C}$ gene. Several liver-specific transcriptional factors are involved. In footprinting analysis, very low concentrations of rat liver nuclear extract could fully protect the whole promoter region. A hypothetical model (Fig. 7) showed a cluster of transactivating proteins, continuously superimposed on this narrow region. Within the upstream region of $n t-5$ to -45 , there is almost no space for the binding site of TATA-binding protein. Those transactivating proteins probably have a very complicated relationship and also interact with a TBP-TAF complex to mediate activation of RNA polymerase II transcription. It should be especially emphasized that the two hepatocytic transcriptional factors HNF-1 and HNF-3 and one ubiquitous protein NFI-/CTF are essential for the regulation of this promoter. Their relationship and interaction need further investigation.

\section{ACKNOWLEDGMENTS}

We wish to thank Drs. J.E. Darnell, Jr., and R.H. Costa for the gifts of pCMV/HNF- $3 \alpha$, pCMV/HNF-3 $\beta$, pTZ18U/HNF$3 \tau$, pLEN4S plasmids, and anti-HNF- $3 \alpha, \beta$ antibodies, Dr. D.V. Brenner for pMT-NFI- plasmid, and Dr. R. Tjian for antisera against NFI-. We thank Dr. M. Yaniv for the gift of pRSV/HNF1 plasmid and Dr. M. Takiguchi for the gifts of pEF-C/EBP- $\alpha$, $\mathrm{C} / \mathrm{EBP}-\beta$, and $\mathrm{C} / \mathrm{EBP}-\delta$ plasmids.

This study was supported by grant NSC 83-0412-B-002-159M02 from the National Science Council, Republic of China.

\section{REFERENCES}

BEATO, M. (1989). Gene regulation by steroid hormones. Cell 56, 335-344.

BERG, L.-P., WHITE, D.A., ALHAQ, A., KAKKAR, V.V., and COOPER, D.N. (1994). Disruption of a binding site for hepatocyte nuclear factor-1 (HNF-1) in the protein C (PROC) gene promoter is associated with hereditary thrombophilia. Hum. Mol. Genet. 3, 2147-2152.

BOHINSKI, R.J., di LAURO, R., WHITSETT, J.A. (1994). The lungspecific surfactant protein $B$ gene promoter is a target for thyroid 
transcription factor 1 and hepatocyte nuclear factor 3 , indicating common factors for organ-specific gene expression along the foregut axis. Mol. Cell. Biol. 14, 5671-5681.

BRENNAN, R.G. (1993). The winged-helix DNA-binding motif: another helix-turn-helix takeoff. Cell 74, 773-776.

BROEKMANS, A.W., CONARD, J., van WEYENBERG, R.G., HORELLOU, M.H., KLUFT, C., and BERTINA, R.M. (1987). Treatment of hereditary protein C deficiency with stanozolol. Thromb. Haemost. 57, 20-24.

CHOUARD, T., BLUMENFELD, M., BACH, I., VANDEKERCK HOVE, J., CEREGHINI, S., and YANIV, M. (1990). A distal dimerization domain is essential for DNA-binding by the atypical HNF1 homeodomain. Nucleic Acids Res. 18, 5853-5863.

DÄHLBACK, B. (1995). Inherited thrombophilia: resistance to activated protein $C$ as a pathogenic factor of venous thromboembolism. Blood 3, 607-614.

DEGEN, S.J.F. (1992). The prothrombin gene and its liver-specific expression. Semin. Thromb. Haemost. 18, 230-242.

FAISST, S., and MEYER, S. (1992). Compilation of vertebrateencoded transcription factors. Nucleic Acids Res. 20, 3-26.

FOSTER, D.C., YOSHITAKE, S., and DAVIE, E.W. (1985). The nucleotide sequence of the gene for human protein C. Proc. Natl. Acad. Sci. USA 82, 4673-4677.

FURIE, B., and FURIE, B.C. (1988). The molecular basis of blood coagulation. Cell 53, 505-518.

GALAS, D., and SCHMITZ, A. (1978). DNase footprinting: a simple method for the detection of protein-DNA-binding specificity. Nucleic Acids Res. 5, 3157-3170.

GLADSON, C.L., SCHARRER, I., HACH, V., BECK, K.H., and GRIFFIN, J.H. (1988). The frequency of type 1 heterozygous protein $S$ and protein $C$ deficiency in 141 unrelated young patients with venous thrombosis. Thromb. Haemost. 59, 18-22.

GORSKI, K., CARNEIRO, M., and SCHIBLER, U. (1986). Tissuespecific in vitro transcription from the mouse albumin promoter. Cell 47, 767-776.

GRONOSTAJSKI, R.M. (1985). Site-specific DNA binding of nuclear factor I: analyses of cellular binding sites. Mol. Cell. Biol. 5, 964-971.

HUANG, M.N., HUNG, H.L., STANFIELD-OAKLEY, S.A., and HIGH, K.A. (1992). Characterization of the human blood coagulation factor X promoter. J. Biol. Chem. 267, 15440-15446.

JACKSON, D.A., ROWADER, K.E., STEVENS, K.Y., JIANG, C., MILOS, P., and ZARET, K.S. (1993). Modulation of liver-specific transcription by interactions between hepatocyte nuclear factor 3 and nuclear factor 1 binding DNA in close apposition. Mol. Cell. Biol. 13, 2401-2410.

KIM. T.K., and ROEDER, R.G. (1994a). CTD-like sequences are important for transcriptional activation by the proline-rich activation domain of CTF1. Nucleic Acids Res. 22, 251.

KIM, T.K., and ROEDER, R.G. (1994b). Proline-rich activator CTF1 targets the TFIIB assembly step during transcriptional activation. Proc. Natl. Acad. Sci. USA 91, 4170-4174.

KURACHI, K., and KURACHI, S. (1995). Regulatory mechanism of the factor IX gene. Thromb. Haemost. 73, 333-339.

LAI, E., and DARNELL, J.E., Jr. (1991). Transcriptional control in hepatocytes: a window on development. Trends Biochem. Sci. 16, 427-430.

LAI, E., PREZIOSO, V.R., SMITH, E., LITVIN, O., COSTA, R.H., and DARNELL, J.E. (1990). HNF-3A, a hepatocyte-enriched transcription factor of novel structure is regulated transcriptionally. Genes Dev. 4, 1427-1436.

LAI, E., PREZIOSO, V.R., TAO, W., CHEN, W.S., and DARNELL, J.E. (1991). Hepatocyte nuclear factor $3 \alpha$ belongs to a gene family in mammals that is homologous to the Drosophila homeotic gene fork head. Genes Dev. 5, 416-427.

LEE, Y.M., TSAI, W.H., LAI, M.Y., CHEN, D.S., and LEE, S.C.
(1993). Induction of liver $\alpha 1$-acid glycoprotein gene expression involves positive and negative transcription factors. Mol. Cell. Biol. 13, 432-442.

LI, S., and ROSEN, J.M. (1994). Distal regulatory elements required for rat whey acidic protein gene expression in transgenic mice. $J$. Biol. Chem. 269, 14235-14243.

McPHERSON, C.E., SHIM, E.-Y., FRIEDMAN, D.S., and ZARET, K. (1993). An active tissue-specific enhancer and bound transcription factors existing in a precisely positioned nucleosomal array. Cell 75, 387-398.

MERCURIO, F., and KARIN, M. (1989). Transcription factors AP-3 and AP-2 interact with the SV40 enhancer in a mutually exclusive manner. EMBO J. 8, 1455-1460.

MIAO, C.H., and DAVIE, E.W. (1995). Transcriptional regulation of human protein $\mathrm{C}$ gene. Blood 86 (Suppl. 1):79a [Abstract].

MIAO, C.H., LEYTUS, S.P., CHUNG, D.W., and DAVIE, E.W. (1992). Liver-specific expression of the gene coding for human factor X, a blood coagulation factor. J. Biol. Chem. 267, 7395-7401.

NEHLS, M.C., RIPPE, R.A., VELOZ, L., and BRENNER, D.A. (1991). Transcription factors nuclear factor I and SP1 interact with the murine collagen $\alpha 1$ (I) promoter. Mol. Cell. Biol. 11, 4065-4073.

NISHIYORI, A., TASHIRO, H., KIMURA, A., AKAGI, K., YAMAMURA, K.-I., MORI, M., and TAKIGUCHI, M. (1994). Determination of tissue specificity of the enhancer by combinatorial operation of tissue-enriched transcription factors. J. Biol. Chem. 269, 1323-1331.

ORI, A., and SHAUL, Y. (1995). Hepatitis B virus enhancer binds and is activated by the hepatocyte nuclear factor 3. Virology 207, 98-106.

OVERDIER, D.G., PORCELLA, A., and COSTA, R.H. (1994). The DNA-binding specificity of the hepatocyte nuclear factor $3 /$ forkhead domain is influenced by amino acid residues adjacent to the recognition helix. Mol. Cell. Biol. 14, 2755-2766.

POORT, S.R., PABINGER-FASCHING, I., MANNHALTER, C., REITSMA, P.H., and BERTINA, R.M. (1993). Twelve novel and two recurrent mutations in 14 Austrian families with hereditary protein C deficiency. Blood Coag. Fibrinolysis 4, 273-280.

REITSMA, P.H., BERNARDI, F., DOIG, R.G., GANDRILLE, S., GREENGARD, J.S., IRELAND, H., KRAWCZAK, M., LIND, B., LONG, G.L., POORT, S.R., SAITO, H., SALA, N., WITT, I., and COOPER, D.N. (1995). Protein C deficiency: a database of mutations, 1995 update. Thromb. Haemost. 73, 876-889.

ROBINS, D.M., SCHELLER, A., and ADLER, A.J. (1994). Specific steroid response from a nonspecific DNA element. J. Steroid Biochem. Mol. Biol. 49, 251-255.

SANTORO, C., MERMOD, N., ANDREWS, P.C., and TJIAN, R. (1988). A family of human CCAAT-box-binding proteins active in transcription and DNA replication: cloning and expression of multiple cDNAs. Nature 334, 218-224.

SCHREIBER, E., MATHIAS, P., MÜLLER, M.M., and SCHAFFNER, W. (1989). Rapid detection of octamer binding proteins with "miniextracts," prepared from a small number of cells. Nucleic Acids Res. 167,6419 .

SLADEK, F.M., and DARNELL, J.E. (1992). Mechanisms of liverspecific gene expression. Curr. Opin. Genet. Dev. 2, 256-259.

SLADEK, F., ZHONG, W., LAI, E., and DARNELL, J.E., Jr. (1990). Liver-enriched transcription factor HNF-4 is a novel member of the steroid hormone receptor superfamily. Genes Dev. 4, 2353-2365.

TAIT, R.C., WALKER, I.D., ISLAM, S.I.A.M., MCCALL, F., CONKIE, J.A., WIGHT, M., MITCHELL, R., and DAVIDSON, J.F. (1993). Protein C activity in healthy volunteers: influence of age, sex, smoking and oral contraceptives. Thromb. Haemost. 70, 281-285.

TANESE, N., PUGH, B.F., and TJIAN, R. (1991). Coactivators for a proline-rich activator purified from the multisubunit human TFIID complex. Genes Dev. 5, 2212-2224. 
TRONCHE, F., and YANIV, M. (1992). HNF1, a homeoprotein member of the hepatic transcription regulatory network. BioEssays 14, 579-587.

TSAY, W., GREENGARD, J.S., MONTGOMERY, R.R., MCPHERSON, R.A., FUCCI, J.C., KOERPER, M.A., COUGHLIN, J., and GRIFFIN, J.H. (1993). Genetic mutations in ten unrelated American patients with symptomatic type 1 protein $\mathrm{C}$ deficiency. Blood Coag. Fibrinolysis 4, 791-796.

XIAO, H., LIS, J.T., XIAO, H., GREENBLATT, J., and FRIESEN, J.D. (1994). The upstream activator CTF/NF1 and RNA polymerase II share a common element involved in transcriptional activation. Nucleic Acids Res. 22, 1966-1973.

\author{
Address reprint requests to: \\ Woei Tsay, M.D. \\ Department of Internal Medicine \\ National Taiwan University \\ College of Medicine \\ No. 7, Chung-Shan South Road \\ Taipei, Taiwan \\ Republic of China
}

Received for publication April 24, 1996; revised June 17, 1996; accepted July 10, 1996. 